\title{
EMPATHY IN EARLY CHILDHOOD:A PRELIMINARY STUDY
}

\author{
CharynaAyuRizkyanti \\ Faculty of Psychology Pancasila University \\ E-mail:charyna@univpancasila.ac.id
}

\author{
Ade Iva Murty \\ Faculty of Psychology Pancasila University \\ E-mail:adeiva.murty@,univpancasila.ac.id).
}

\begin{tabular}{|l|l|l|} 
Diterima: 12 November 2018 & Direvisi : 24 November 2018 & Diterbitkan: 31 Desember 2018 \\
\hline
\end{tabular}

\begin{abstract}
Nowadays, bullying is still becoming an unsolvable issue in Indonesia. Among students, bullying phenomenon happens started from kindergarten level untill bigh school level. By having empathy, children are being much more understanding, more adept at handling anger and daring to say no to commit violence, including bullying. This current research examines the preschoolers' empatby through self-report in response to short clip. The short clip assesses the extent to which children endorsed behaviours that were regarded as showing their empathy towards others (cognitive and affective). A total of 50 preschoolers with age 4-6 year old participated in this study. By decriptive analysis, result found that all preschoolers with the exception of a few showed empathy in two components, both cognitive and affective. This study implies that in order to elevate children's empathy, parents must be modelling how to identify and express emotions toward them.
\end{abstract}

Keywords:Empathy, preschooler, cognitive-affective empathy, compassionate

\begin{abstract}
Abstrak
Saat ini, intimidasi masih menjadi masalah yang tidak dapat diselesaikan di Indonesia. Di kalangan siswa, fenomena bullying terjadi mulai dari tingkat TK hingga tingkat SMA. Dengan memiliki empati, anak-anak menjadi jauh lebih pengertian, lebih mahir dalam menangani kemarahan dan berani mengatakan tidak untuk melakukan kekerasan, termasuk bullying. Penelitian saat ini meneliti empati anak-anak prasekolah melalui laporan diri sebagai tanggapan terhadap klip singkat. Klip pendek menilai sejauh mana anak-anak mendukung perilaku yang dianggap menunjukkan empati mereka terhadap orang lain (kognitif dan afektif). Sebanyak 50 anak prasekolah dengan usia 4-6 tahun berpartisipasi dalam penelitian ini. Dengan analisis deskriptif, hasil menemukan bahwa semua anak prasekolah dengan pengecualian beberapa menunjukkan empati dalam dua komponen, baik kognitif dan afektif. Studi ini menyiratkan bahwa untuk meningkatkan empati anak, orang tua harus menjadi model bagaimana mengidentifikasi dan mengekspresikan emosi terhadap mereka.
\end{abstract}

Kata kunci: Empati, anak prasekolah, empati kognitif-afektif, penyayang

\section{Introduction}

Until now, bullying is still one of the biggest problems that occur in education in Indonesia. According to Indonesian Child Protection Commission (KPAI), a total of $84 \%$ children in Indonesia experience violence at school. ${ }^{25}$ The number of school violence in Indonesia is even higher than in Vietnam and Nepal (79\%), Kamboja (73\%) ad also Pakistan (43\%). Furthermore, KPAI states that Bullying which is one of the forms of violence in schools beats student brawl, educational discrimination, or complaints of illegal levies. ${ }^{1}$

To cope with violence behaviour, enhancing our children's moral intelligence is deemed important so that they might do act as well as think right by protecting their moral 
life. Among many virtues, empathy is the the first essential virtue which is considered as the key to support a sense right and wrong. ${ }^{2}$ Particularly for children, empathy is a key to prevent bullying and many other forms of cruelty.

Empathy is simply defined as the ability to feel for another person emerges early in life long before the child is able to report on such abilities. Empathy is not only motivates us to help and desire juctice for others, but also inhibits aggression toward them. ${ }^{3,45}$ Many studies report that empathy is negatively correlated with aggression. ${ }^{6,7}$ and positively correlated with altruistic behaviour. ${ }^{8}$

Davis (1994) assumed a model of empathy as a stable trait consisting of both cognitive and emotional components. ${ }^{9}$ As a set of constructs, empathy is related with the responses of one individual to the experiences of another and further advised the consideration of a multi-dimensional approach. Thus, many research had investigated how cognitive and affective empathy interact. ${ }^{10}$ The term cognitive empathy refers to the ability to understand intellectually the perspective of another person and, in so doing, understand another's emotional state; and affective empathy is generally used to refer to having an affective response congruent with that of another's emotional state. $^{11,12}$

The emergence of empathy can be seen in children since they were born. Although it grows naturally, family and environment must cultivate a child to develop his/her empathy since very early age. Furthermore, Hoffman (2007) divided empathy into four levels: ${ }^{13}$

1. Global empathy. In the first year children may match the emotions they witness. The newborn infants appears crying while another infant is crying, a mother smiles at her baby and the baby catches her emotion and smiles back. This sort of crying seems to match the emotion of others because the infants can not clearly distinguish between his distress and other's distress.

2. The egocentric empathy. The empathy gradually move in to difference reaction in toddler stage. From the second year on children actively offer help. The kind of help offered is what they themselves would find comforting and is in that sense egocentric Now children show their effort to connect another person's discomfort with their own. For example, while she saw her mother crying, she was giving her mother something to make her mother feels better. However, it is unclear whether she understands what her mother feeling Piaget \& Vygotsky called this behaviour with an egocentric thinking; nevertheless, the child at least responds with appropriate empathuc efforts.

3. Empathy for another's feeling. In the third year, with the emergence of role taking skills, children become aware that other people's feelings can differ from their own. By the time a child at preschool years, now children begin to develop role-taking capabilities and associate their emotions with the feelings of others. The child recognizes that someone's feeling may be different from his feeling, thus, he tries to find simple ways to comfort. No wonder, children in this age become more helpful and caring to others. Their responses to distress may thus become more appropriate to the other person's needs.

4. Empathy for another's life condition, by late childhood or early adolescence 
children become aware that others' feelings may not just be due to the immediate situation but stem from their more lasting life situation. Empathy may also be found with respect to entire groups of people (the poor, the oppresses, etc) and thus transcend immediate experience.

Generally, females are assumed to show more empathic responses than are their male counterparts. The different social roles assigned to females and males within society influences their opportunities to practice and learn about empathy may explain about gender differences. Traditionally, females are expected to be highly emotional and caring, whereas male are often depicted as being less emotional and stronger in time of weakness. $^{14,15}$

Several scales have been developed to measure empathy, however, it still has each weaknesses. ${ }^{16}$ Bryant (1982) developed The Empathy Index for Children and Adolescents (IECA) to assess dispositional affective empathy in children 6 years and older. ${ }^{17}$ There is a 22 -item self-report questionnaire which has been used in numerous studies with children and adolescents. Although the IECA demonstrated acceptable test-retest reliability and preliminary construct validity, the itemtotal correlations and the reliability formulas indicated weak internal consistency, especially in the two younger age samples.

The most common scale to measure empathy has been developed by Davis (1980), namely The Interpersonal Reactivity Index (IRI) to measure adult's empathy. ${ }^{18}$ This scale of four subscales:

1. Perspective-taking which assess spontaneous attempts to adopt the perspectives of other people and see things from their point of view;

2. Fantasy which measures the tendency to identify with characters in movies, novels, plays and other fictional situation;

3. Empathic concern that inquires about respondents' feelings of warmth, compassion, and concern for others;

4. The personal distress scale wich measures the personal feelings of anxiety and discomfort that result from observing another's negative experience.

The IRI has good psychometric properties but it is not suitable for use with children $^{11}$, thus, Litvack-Miller, McDougall \& Romney (1997) has modified IRI for measuring children's empathy. ${ }^{19}$ The IRI for children constructed a 22 item scale which is reworded from the original IRI to be used by first grade children. However, it is still difficult to use the modifeid IRI for preschoolers considering not all of them is neither able to read nor focus on 22 questions.

Considering that there hasn't been any scale yet to measure empathy among preschoolers, thus, this current research examines the preschoolers' empathy through self-report responses. This research used one clip that aimed to assess the extent to which children endorsed behaviours that were regarded as showing their empathy towards others, both cognitive and affective.

\section{METHOD}

There were 50 preschoolers age $4-7^{\text {th }}$ years old which randomly assigned by their teacher in Islamic Kindergarten which is located in Cinere Depok, West Java. All measures were completed in a quiet room where respondents viewed a clip from laptop and afterwards answered some questions given by the interviewer. The clip was taken from youtube to identify preschoolers' empathy which is about $1.5 \mathrm{~min}$ length. The event depicts one particular scene where a 
baby and her parents were playing a doll together. The doll was showed sucking a nipple and soon the doll's crying while the nipple is being taken off from its mouth. The clip showed how was the baby reaction while she hears the crying voice of the doll. In brief, the event depicted the baby cries while seeing her dolls crying. After watching the clip, each child was given some questions to respond it.

In research on empathy, a distinction is typically made between affective and cognitive empathy. ${ }^{9,10,5}$ Affective empathy concerns the vicarious experience of emotions consistent with those of others, that is feeling with others; while cognitive component involves understanding another's feelings, whether by means of simple associations or more complex perspective taking processes. ${ }^{20}$

Zhou, Valiente\& Eisenberg (in Garton \&Gringart, 2005) reviewed the methods generally used in the research literature to measure empathy, namely selfreport with picture stories, self report questionnaires and self report in simulated experimental situation. ${ }^{21}$ This research used open-ended questions, where interviewer has already set up some questions to gain both cognitive and affective component of children's empathy. The responds were determined using a 1-3 score. Score 1 was given when the child's answer showed no empathy, score 2 indicated the child showed his empathy but with unrelevant answer (didn't match with the real context) and score 3 indicated the child has empathy with relevant answer (matched with the real context).

\section{RESULT}

A frequency distribution was used to get the children's answer based on the clip, in addition to a qualitative analysis of their responses:

\section{Cognitive Empathy}

$90 \%$ of the children showed their empathy based on cognitive component by unrelevant answers which didn't happen on the clip. For example, "the baby's crying because he got no milk, .. because the doll was taken away from the baby,.. the sound of the doll was scared the baby, the baby's crying because she wants to get pup,... because the baby cant see her mommy,... her mommy is having window shopping, ..” etc. These sort of answers may go awry because children answered through their own point of view, not others.

While $8 \%$ of them gave the right answer based on cognitive point of view. Those children could answered precisely based on the event context. These children gave the right answerd such as, "the baby is crying because he is watching the doll's crying or listening the sound of crying doll". Only $2 \%$ of the child failed to answer with saying, 'I don't know". However, even the child cant show his empathy base on cognitive component, next he still can give the right answer when the question comes to affective empathy component.

Further, interviewer asked the children what will they do if they are being there at that time. $96 \%$ of the children gave a various answer in order to make the baby stops crying in a proper way, such as ask the baby to play, give him a milk, try to make the baby sleep, carry the baby, etc. Notwithstanding the answers, the point is the children showed their willingness to give a help. Meanwhile, the remaining 4\% gave the unusual treatment, such as "let the baby alone.., give him your handphone,etc". All those answers obviously were reflected the way they are treated by their parents in daily life. 
$92 \%$ of the children gave the right answer in accordance to show their empathy of affective component. Most of the children showed their affective empathy by saying "the baby is feeling sad". Children interpreted being sad while the event depicted the baby's crying. Regardless of wrong answer they had given for cognitive component, most of them are succeeded to gain the right answer for affective component.

Only $8 \%$ children gave answers which was revealed the opposite feeling with the truth condition. It could be happened because of children didn't seem serious to respond the instruction eventhough the questions have been repeated twice by the interviewer.

Next question was straight to the point asked to children whether they had ever helped other people. 100\% said yes, they all have ever had helped others that can be their parents, sisters or brothers, friends, teachers, etc. Then, the interviewer asked concern with how did they feel if they succeeded to make the baby smiles. $90 \%$ of the children said that they feel happy while looking the baby's smile. $8 \%$ of them said they don't feel anything, while $2 \%$ remains gave the opposite answer with the truth condition.

\section{DISCUSSION}

The findings of this study suggest that all preschoolers with the exception of a few showed empathy in two components, both cognitive and affective. The present data reveal that the affective empathy development is much more better than cognitive empathy at this preschool age.

From cognitive point of view, it is clear that children at this age are still difficult to get another's perspective. Piaget (in Papalia, Old \&Fieldman, 2009) described this preschooler age as the preoperational thinking stage, which one prominent characteristic is called egocentricsm which actually shows children's thinking limitation. ${ }^{22}$ Accotding to Piaget, young children center so much on their own point of view that they can not take in another's. three-year-old are not as egocentric as newborn babies, but, they still think the universe center on them. It may help explain why preschoolers sometimes have trouble separating reality what goes inside their own heads and why they may show confusion about what causes what.

In accordance with the current result study how children's ability in cognitive empathy, it showed their thinking capacity still limited. The way children's answers were very spontaneous and subjective. It shows how children view the world in terms of themselves whith self-centered features. So that, they easily judge something only based on their daily experience. In informal followup interviews with some of the kindergarten teachers it emerged some facts related with children's answers which obviously were reflected the way they are treated by their parents in daily life. When a child said that the way to make the baby calmed was giving her your handphone, as a matter of facts, that is how the child being raised up by his parents.

Cognitive empathy can be explain by the concept with theory of mind (Piaget in Flavell et al., 1995). ${ }^{23}$ It is about the emerged of an awareness of one's own mental processes and those of other people. When we ask children such as, "Where do dreams come from?" and "What do you think with?", by children's answer, it concluded that children younger than age 6 can't distinguish between thoughts and dreams and real physical entities and have no theory of mind.

In terms of affective empathy, Hoffman (2000) stated that it has existed since the early birth of the child. ${ }^{4} \mathrm{New}$ research has shown that empathy begins so early that it may be "an innate potential, like the ability to learn language".. It could explain 
why babies criy when they see another child crying. Like empathy cognitive, this empathy affective may reflect a growing abillity to feel how another person might feel. Even before the age 2, children often help others, share belongings and food, and offer comfort.

Zoll\&Enz (2002) added that affective empathy could be the result of cognitive empathy. ${ }^{24}$ It relates to the process where emotions in the observer emerge due to perception of internal states in the target. Thus, affective empathy suppose to grow along with cognitive maturity. At this age (3-6 year-old), environment doesn't have to force children in order to do some empathic things. It may develop automatically when they grow up.

However, environment particularly family is important as a model and a source of explicit standards of behaviour. ${ }^{25}$ Parents of empathic children typically are empathize themselves. They point out models of empathic behaviour and steer children toward stories, films, and television pragrams that depict cooperation, sharing, generousity and helpfullnes. Borba (2002) found four ways how parents should show their empathy first by tuning in to their child's feelings and listening with empathy, akcnowledging what causes the emotion, labelling how the child is feeling and last but not least is kindling a resolution for the child's need. ${ }^{2}$

Furthermore, this ability to empathize caused feeling pleasure inside of them. It describes how satistfied and happy they feel while looking other's happiness. Most of the children said they feel more better or happy after gave some helps toward others. As we know that children are becoming unhappier these days as life becomes more competitive, with higher expectations of children and young people, increasing pressure and examinations at school.

\section{CONCLUSION}

The findings of this study suggest that empathy shoud be built continuously both at home and school in order to achieve the highest empathy. Regardless of children's limited capacity thinking, the cognitive ability to distinguish between the self and the other is essential for empathy. In order to achieve children's comprehension in empathy, they must learn how to identify and express emotions. ${ }^{2}$ They have tremendous difficulty feeling for the other person simply because they may not recognize the other's hurt, discomfort, anxiety, pride, happiness and even anger. Children need an education that provides stronger emotional intelligence, an adequate vocabulary of feelings and then the encouragement to use it.

\section{RECOMMENDATION}

The findings, however, is a beginning to gain more comprehensive study related with young children's empathy. This descriptive study should be interpreted in the context of certain limitations. Furthermore, it should be taken into account that our data are based on self-report measures. It is acknowledge by those interested in this field that further studied may provide additional evidence needed.

\section{REFERENCES}

Firmansyah, T. (15 Oktober 2014). Aduan bullying tertinggi. Republika.co.id. Diunduhdarihttp://www.republika.co .id/berita/koran/halaman1/14/10/15/ndh4sp-aduan-bullyingtertinggi

Borba, M. (2002). Building moral intelligence: The seven essential virtues that teach kids to do the right thing. San Fransisco: Jossey Bass

Batson, C.D. (1991). The altruism question: Toward a social- psychological answer. Hillsdale, NJ: Erlbaum.

Hoffman, M.L. (2000). The measurement of empathy. In C. E. Izard (Ed.), 
Measuring emotions in infants and children (pp. 279-296). Cambridge, UK: Cambridge

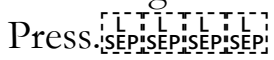

Miller, P.A., \& Eisenberg, N. (1988). The relation of empathy to aggressive and externalizing/antisocial behavior. Psychological Bulletin, 103, 324344. SEEPISEP

Mehrabian, A. (1997). Relations among personality scales of aggression, violence, and empathy: Validational evidence bearing on the Risk of Eruptive Violence Scale. Aggressive Behavior, 23, 433-445.

Kaukiainen, A., Björkqvist, K., Lagerspetz, K., Österman, K., Salmivalli, C., Rothberg, S. \&Ahlbom, A. (1999). The relationships between social intelligence, empathy, and three types of aggression. Aggressive Behavior, 25,



Batson, C.D., \& Coke, J.S. (1981). Empathy: A source of altruistic motivation for helping? Hillsdale, NJ: Erlbaum.

Davis MH (1994) Empathy: A social psychological approach. Dubuque, Iowa: Brown

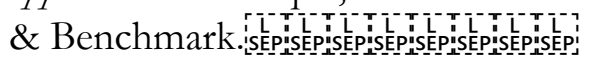

Duane C, Hill, CE (1996) The current state of empathy research. Journal of Counseling Psychology, 43, 261-274

Davis, M. (1983). Measuring individual differences in empathy: Evidence for a multidimensional approach. Journal of Personality and Social Psychology, 44, 113-126.

Eisenberg, N., \& Strayer, J. (1987). Empathy and its Development. Cambridge, UK: Cambridge University Press. [LE-p]

Hoffman, M. L. (2007). The origins of empathy morality in toddlerhood. Socioemotional Development in The Toddler Years Journal, 132-145..

Eisenberg, N., Fabes, R., Carlo, G., Troyer,
D., Speer, A., Karbon, M., \& Switzer, G. (1992). The relations of maternal practices and characteristics to children's vicarious emotional responsiveness. Child

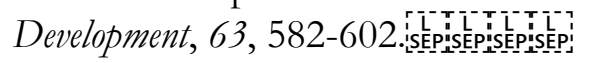

Spinrad, T., Losoya, S., Eisenberg, N., Fabes, R., Shepard, S., Cumberland, A., et al. (1999). The relations of parental affect and encouragement to children's moral emotions and behaviour. Journal of Moral Education, 28(3), 323-337.

Lawrenca, E. J., Shaw, P., Baker, D, BaronCohen \& David, S. (2004). Measuring empathy: reliability and validity of the empathy quotient. Psychological Medicine, 34, 911-924.

Bryant, B. (1982). An index of empathy children and adolescents. Child Development, 53, 413-425.

Davis, M. (1980). A multidimensional approach to individual differences in empathy. Catalogue of Selected Documents in Psychology, 10(85).

Litvack-Miller, W., McDougall, D. \& Romney, D. M. (1997). The structure of empathy during middle childhood and its relationship to prosocial behavior. Genet Soc Gen Psychol Monogr, 123(3), 303-324.

De Wied, M., Maas, C., van Goozen, S., Vermande, M., Engels, R., Meeus, W., Matthys, W \&Goudena, P. (2007). Bryant's empathy index: A closer examination of its internal structure. European Journal of Psychological Assessment, 23(2), 99-104.

Garton, F.A. \&Gringart, E. (2005). The development of a scale to measure empathy in 8- and 9- year old children. Australian Journal of Education and Developmental Psychology, 5, 17-25.

Papalia, D. E., Olds, S. W. \& Feldman, R. D. (2009). Human Development. $5^{\text {th }}$ Ed. McGraw-Hill. 
Flavel, J. H., Green, F. L. \& Flavell, E. R. (1995). Young children's knowledge about thinking. Monographs of the Society for Research in Child Development, 60(243).

Zoll, C. \&Enz, S. (2002). A questionnaire tassess affective and cognitive empatby in children. Retrieved fromhttp://opus4.kobv.de/opus4../208

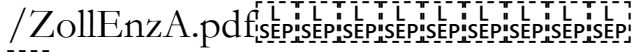

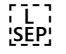

Mukhtar, U. (2017, 22 Februari). Indonesia peringkattertinggikasuskekerasan di sekolah.https://www.republika.co.id/ berita/nasional/umum/17/02/22/ol qnn2383-indonesia-peringkattertinggi-kasus-kekerasan-di-sekolah 